\title{
Detection of Mice DNA in Meatballs Using Real Time - PCR
}

\author{
Triayu Septiani ${ }^{1)}$, Pendrianto ${ }^{2)}$ \\ ${ }^{1)}$ Halal Research Center, YARSI Research Institute, Jakarta \\ ${ }^{2)}$ Telomere Research Center, YARSI Research Institute, Jakarta \\ *Corresponding author's email: triayu.septiani@yarsi.ac.id
}

\begin{abstract}
Meat is one of perishable food and has the high of water content and protein content. Meatballs are processed food who are using meat as main ingredient and other ingredients, such tapioca flour, salt, pepper, and the other ingredients as food additives. Meatballs is the mostpopular because has tasty flavor, high protein content, especiallyessential amino acids.In Indonesia, until now there were still cases of counterfeiting of processed meat products. One of method is mixing the beef meat and other animalsmeat in the making process to reduce production costs, so that similar products can be obtained at a much lower cost. One common case is the mixing of beef meat with rat meat. This study aims to identify meatballs contaminated by rat meat. Meatball samples used do not have Halal certificate from LPPOM MUI. From the results of the study, obtained the green amplification curve with the highest peak showed positive control of rat DNA, followed by three other green curves from the sample that showed the occurrence of amplification, thus indicating samples positive containing rat DNA. In the positive sample, the rat DNA concentration in the sample is quite low which can be seen from the intensity of the peak produced on the amplification curve when compared with positive control.
\end{abstract}

Keywords :DNA, Meat,Meatballs, Rat, RT-PCR

\section{PENDAHULUAN}

Keamanan pangan sendiri erat kaitannya dengan halal dan thayyiban. Thayyib adalah sebuah kata sifat yang berfungsi paling dasar untuk menyatakan kualitas yang menjelaskan perasaan seperti sangat menggembirakan, senang dan manis.Identifikasi spesies hewan sangat penting dibutuhkan untuk verifikasi food labelling yang dibutuhkan oleh European Union Regulations.Identifikasi spesies sangat relevan untuk kepentingan konsumen dalam hal ekonomi, kesehatan, atau alasan keagamaan. Namun kekurangan dari teknik ini adalah tidak dapat digunakan untuk mengidentifikasi spesies pada produk yang mengalami proses pemanasan, hal ini dikarenakan protein cenderung tidak tahan panas dibanding DNA yang lebih stabil dibanding protein saat proses pemanasan, bahkan jika DNA terfragmentasi oleh pemanasan, teknik identifikasi modern DNA tetap dapat mengidentifikasi DNA dari spesies yang berbeda pada sampel (Farag, 2015).

Daging tikus merupakan bahan pangan yang tidak halal dalam ajaran islam, sehingga kehadirannya dalam suatu bahan makanan merupakan isu yang penting. Widyasari (2015) menggunakan primer spesifik untuk mitokondria b Rattus argentiventer yang dapat digunakan untuk mendeteksi kontaminasi daging tikus pada formulasi bakso yang digunakan. Spesifisitas dari primer telah dikonfirmasi dari jaringan segar babi, sapi, ayam, domba, kelinci, dan tikus putih atau tikus laboratorium. Primer yang telah di desain kemudian digunakan untuk menganalisis DNA daging tikus pada formulasi bakso yang dibuat dari campuran daging tikus dan sapi dengan perbandingan 1 , $2,3,5,10,25,50$ dan $100 \%$. Pengulangan pengujian dilakukan dengan mengukur amplifikasi dari jaringan segar tikus dan daging tikus pada bakso.

Pada banyak kasus, analisis semi kuantitatif dapat mengestimasi kandungan daging dari spesies yang berbeda pada sampel.Pengembangan dari metode biologi molekuler telah memfasilitasi identifikasi tanaman, bakteri, dan spesies binatang dengan keakuratan yang tinggi. Regulasi yang dikeluarkan oleh EC legislation menyatakan bahwa seluruh produsen makanan pada rantai supply makanan harus dapat mengidentifikasi sumber dari bahan mentah yang digunakan (Murugaiah, 2009).

PCR adalah metode yang tepat untuk digunakan mendeteksi DNA tikus 
pada produk daging olahan bakso. Prinsip dasar dari metode PCR adalah reaksi berantai, dimana dari satu molekul DNA akan dihasilkan dua kopi, kemudian empat, delapan dan seterusnya. Proses replikasi ini dihasilkan dari protein spesifik yang dikenal dengan polymerase, yaitu enzim yang bersama dengan molekul DNA dapat membangun sikuens basa DNA yang spesifik terhadap setiap spesies (Joshi, 2011). Pada penelitian ini, deteksi cemaran daging tikus akan dideteksi dengan menggunakan Real Time - PCR, dimana akan digunakan kontrol positif berupa sikuens basa DNA spesifik spesies tikus.

\section{METODOLOGI}

\section{Bahan dan Alat}

Bahan penelitian adalah berbagai jenis produk bakso dalam keadaan mentah. Produk bakso mentah yang akan dianalisis adalah produk bakso yang dijual di pasar tradisional dan belum memiliki kemasan serta label. Bahan yang digunakan untuk analisis adalah DNeasy Mericon Food dan QuantiNova Sybr Green.Alat yang digunakan pada penelitian ini adalah micro pipet (Eppendorf), Nanodrop Spectrophotometer (Tecan), tips $10 \mu \mathrm{L}, 100$ $\mu \mathrm{L}, 1000 \mu \mathrm{L}$, mesin real time - pcr (Roche LightCycler 480), Thermoblock Biosans dan Vortex.

\section{METODE}

\section{Ekstraksi DNA}

Pengambilan $200 \mathrm{mg}$ sampel dan penambahan $1 \mathrm{ml}$ food lysis buffer (bisa secara langsung $1 \mathrm{ml}$ ataupun bertahap 500 $\mu 1$ dan $500 \mu 1$, tergantung jenis sampel). Dilanjutkan dengan proses purifikasi dengan mengambil $1 \mathrm{ml}$ sampel dan menambahkan 2.5 proteinase $-\mathrm{K}$, vortex dan inkubasi pada suhu $60{ }^{0} \mathrm{C}$ selama 30 menit. Sentrifuge dengan kecepatan $2500 x g$ selama 5 menit.Tambahkan 500 mikrolit Chloroform ke dalam tube $2 \mathrm{ml}$ yang baru.Pindahkan lapisan bening dari lysis tube, tanpa menyentuh presipitasi pada dasar tube.Masukkan ke dalam 500 mikrolit yang berisi Chloroform.Vortex selama 15 detik dan sentrifuge dengan kecepatan 14000xg selama 15 menit.Ambil lapisan bening dan hitung berapa volume, lalu tambahkan 1:1 volume buffer $\mathrm{PB}$ dan vortex selama 15 detik. Tempatkan seluruh cairan ke dalam Qiaquick spin column dan sentrifuge 17900xg selama 1 menit. Buang cairan yang tertampung di collection tube.Tambahkan 500 mikrolit Buffer AW2, sentrifuge 17900xg selama 1 menit dan buang supernatannya.Tempatkan Qiaquick spin column pada $2 \mathrm{ml}$ collection tube yang baru dan sentrifuge ulang pada $17900 x g$ selama 1 menit pada dry membrane. Buang collection tube dan tempatkan Qiaquick spin column pada tube baru $1.5 \mathrm{ml}$. Tambahkan 150 mikrolit buffer EB dan diamkan selama 1 menit pada suhu ruang lalu sentrifuge selama 1 menit. DNA hasil elusi dapat langsung digunakan untuk PCR atau simpan pada suhu $-20{ }^{0} \mathrm{C}$.

\section{Analisis Kemurnian DNA}

Analisis dilakukan menggunakan instrument Tecan Nanodrop Spectrophotometer. Lakukan blank menggunakan Elussion Buffer pada plate, dilanjutkan dengan sampel DNA yang telah diekstraksi diambil sebanyak 2 mikrolit dan diletakkan pada plate Tecan, masukkan kembali plate ke dalam instrument, dan kemudian lakukan pembacaan kemurnian DNA dengan menggunakan blank EB. Hasil kemurnian DNA akan keluar berupa tabel yang meliputi rasio dan konsentrasi DNA.

\section{Analisis RT - PCR}

Pengujian menggunakan real time PCR dilakukan dengan terlebih dahulu membuat larutan PCR Master Mix. Prosedur pembuatan PCR Master Mix dengan QuantiNova Sybr Green PCR Kit yaitu dengan mencairkan 2x QuantiNova Sybr Green PCR Mix, QuantiNova Yellow template dilution buffer,primer mix, RNAse Free water dan template DNA, spin down selama 15 detik, buat PCR Master Mix dalam tabung LifeTouch Microcentrifuge steril $1.7 \mathrm{ml}$ dan campurkan PCR Master mix sesuai jumlah sampel kecuali template, kemudian distribusikan ke dalam tabung reaksi $0.2 \mathrm{ml}$ masing-masing $18 \mu \mathrm{l}$. Tambahkan2 $\mu \mathrm{l}$ template DNA $(\leq 500$ ng/reaksi) ke dalam tabung PCR yang sudah berisi PCR Mix dan running mesin pcr sesuai program yang telah ditentukan dengan jumlah siklus $35-40$.

HASIL DAN PEMBAHASAN

Ekstraksi dan Kemurnian DNA 
Tabel 1. Hasil Ekstraksi DNA

\begin{tabular}{ccccc}
\hline $\begin{array}{c}\text { Sample } \\
\text { ID }\end{array}$ & 260 & 280 & $\begin{array}{c}\text { Conc } \\
\text { ng/ } \mu 1\end{array}$ & Ratio \\
\hline B1 & 0,0355 & 0,019 & 35,5 & 1,87 \\
B2 & 0,05 & 0,0272 & 50 & 1,84 \\
B3 & 0,0379 & 0,0204 & 37,9 & 1,86 \\
B4 & 0,0519 & 0,0276 & 51,9 & 1,88 \\
B5 & 0,037 & 0,0198 & 37 & 1,87 \\
B6 & 0,0232 & 0,0122 & 23,2 & 1,9 \\
B7 & 0,0439 & 0,0237 & 43,9 & 1,85 \\
B8 & 0,045 & 0,0247 & 45 & 1,82 \\
B9 & 0,0486 & 0,0264 & 48,6 & 1,84 \\
B10 & 0,054 & 0,0291 & 54 & 1,86 \\
\hline B11 & 0,0524 & 0,0291 & 52,4 & 1,8 \\
B12 & 0,0506 & 0,0276 & 50,6 & 1,83 \\
B13 & 0,0321 & 0,0175 & 32,1 & 1,83 \\
B14 & 0,0504 & 0,0272 & 50,4 & 1,85 \\
B15 & 0,0715 & 0,0388 & 71,5 & 1,84 \\
B16 & 0,0027 & 0,001 & 2,7 & 1,93 \\
\hline B17 & 0,1044 & 0,057 & 104,4 & 1,82 \\
\hline B18 & 0,1143 & 0,063 & 114,3 & 1,81 \\
\hline B19 & 0,0551 & 0,030 & 55,1 & 1,84 \\
B20 & 0,0013 & 0,001 & 1,3 & 1,86 \\
\hline
\end{tabular}

Tingkat kemurnian dapat ditentukan dengan cara menghitung rasio antara nilai $260 \mathrm{~nm}$ dan $280 \mathrm{~nm}$ pada sampel DNA. Nilai $260 \mathrm{~nm}$ merupakan nilai maksimal DNA dapat menyerap cahaya, nilai tersebut dapat digunakan untuk memperkirakan konsentrasi DNA, sedangkan nilai $280 \mathrm{~nm}$ merupakan nilai maksimal residu protein dapat menyerap cahaya. Tingkat kemurnian DNA dikatakan baik jika nilai rasio Optical Density (OD) 260/280 nm yang diperoleh antara $1.8-2.0$, dan merupakan DNA dengan kemurnian yang tinggi dan tidak terkontaminasi dengan residu protein.

Jumlah seluruh sampel yang digunakan pada penelitian ini adalah dua puluh sampel bakso. Dari kedua puluh sampel yang telah diekstraksi, diperoleh ratio kemurnian konsentrasi DNA tidak boleh $<1.8$ karena hal tersebut menandakan DNA yang diekstraksi terkontaminasi oleh RNA dan kemurnian DNA juga tidak > 2.0 karena menandakan DNA yang diekstraksi telah terkontaminasi oleh protein. DNA yang diekstraksi harus memiliki kualifikasi ratio 1.8 - 2.0, yang menandakan sampel yang diekstraksi mengandung DNA murni.

Analisis DNA Tikus Menggunakan Real Time - PCR

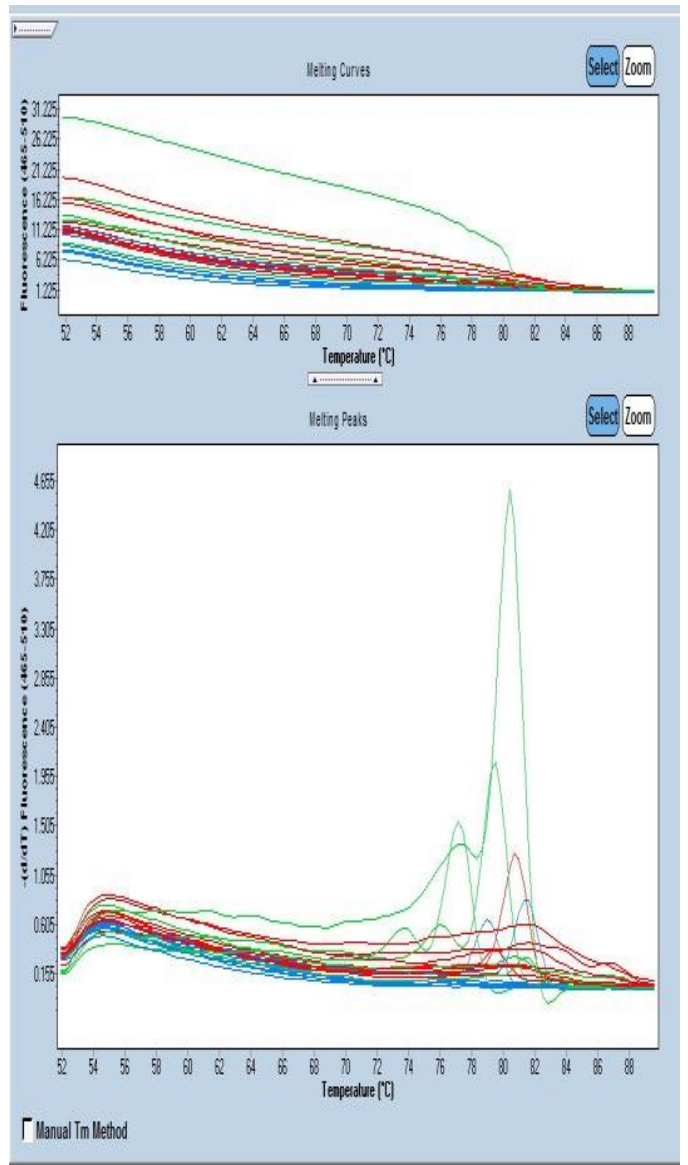

Pada kurva amplifikasi berwarna hijau dengan peak tertinggi menunjukkan kontrol positif DNA tikus, yang diikuti dengan tiga kurva hijau lainnya dari sampel yang menunjukan terjadinya amplifikasi sehingga menandakan sampel positif mengandung DNA tikus.Pada sampel positif, konsentrasi DNA tikus dalam sampel cukup rendah yang dapat dilihat dari intensitas peak yang dihasilkan pada kurva amplifikasi jika dibandingkan dengan kontrol positif. Terjadinya kurva amplifikasi dengan warna lain dapat dikarenakan terdapatnya DNA lain dalam sampel yang ikut teramplifikasi, namun yang terbukti mengandung DNA tikus sesuai dengan kontrol hanya pada tiga sampel.

Pada penelitian ini pengujian DNA tikus dalam produk pangan olahan terbukti akurat dengan menggunakan real time PCR. Srihanto (2011), telah mencoba metode identifikasi jenis daging di dalam produk asal hewan yang bertujuan untuk mencegah terjadinya pemalsuan daging atau substitusi dengan daging lain saat 
pengolahan, dengan menggunakan metode PCR berhasil menemukan amplifikasi DNA pada amplikon 188 bp. Namun, kekurangan dari metode PCR dibandingkan dengan Real Time - PCR adalah pada waktu yg lebih lama saat proses analisis. Kedua metode tersebut, Real Time - PCR dan PCR sama sama memiliki sensitivitas dan spesifisitas yang tinggi.

Salah satu teknik PCR yang juga dapat digunakan untuk mengidentifikasi kontaminan daging yang berasal dari spesies lain pada produk daging sapi olahan adalah dengan menggunakan gen leptin. Pada penelitian yang dilakukan Margawati (2010), mengggunakan gen leptin untuk mendeteksi keberadaan DNA babi dalam produk daging bakso dan ayam. Namun kelemahan dari metode ini adalah tingkat preparasi yang kompleks, persiapan yang rumit, dan memerlukan waktu yang lebih lama. Liquid chromatography dan immunoassay juga merupakan metode yang bisa dilakukan, namun protein akan kehilangan aktivitas biologinya setelah hewan mati dan protein juga bersifat labil dalam kondisi panas, sehingga teknik PCR atau Real Time - PCR merupakan teknik yang lebih akurat dan tepat untuk metode analisis kontaminasi produk daging dengan daging babi atau daging tikus.

\section{Kesimpulan}

Kesimpulan dari penelitian ini adalah metode RT - PCR dengan Quantinova Sybr Green dapat digunakan untuk mendeteksi kontaminan Tikus dalam pangan daging olahan Bakso.Metode ini juga merupakan metode yang cepat, dan reliable sehingga sangat tepat jika digunakan sebagai halal authentication untuk mendeteksi keberadaan tikus dalam pangan olahan.

\section{Saran}

Saran untuk penelitian ini adalah dapat dilakukan pengambilan sampel dengan wilayah yang lebih besar, yaitu di seluruh wilayah DKI Jakarta.Pengujian dengan menggunakan sampel di seluruh wilayah Jakarta perlu dilakukan, mengingat banyaknya kenakalan yang sering dilakukan oleh produsen produk pangan di Indonesia dan analisis dengan metode yang reliable di laboratorium adalah jawaban yang tepat untuk mengetahui kandungan yang sebenarnya dalam suatu produk pangan olahan.

\section{DAFTAR PUSTAKA}

Ayu, B.P., Purbowatiningrum, R.S., Agustina, L.N.A. 2011.Purifikasi DNA Kromosom Geobacillus sp dYTae-14 Menggunakan Kolom Silika dengan Denaturan Urea. Jurnal Sains dan Matematika Vol. 19 (4): 101 - 106 (2011).

Aziz, A.Y. and Vui, C.N. 2012.The Role of Halal Awareness and Halal Certification in Influencing NonMuslim's Purchase Intention.University Putra Malaysia. Third International Conference on Business and Economic Research (3rd ICBER 2012) Proceeding, ISBN: 978967-5705-05-2.

Bohari, A. M., Hin, C. W. and Fuad, N. 2013. The Competitiveness of Halal Food Industry in Malaysia : A SWOT ICT Analysis. Geografia Online Malaysia Journal of Society and Space 9 issue 1 (1 - 9) 1, ISSN 2180-2491.

Heinz, G., Hautzinger, P. 2007. Meat Processing Technology For Small To Medium Scale Producers. FAO Regional Office For Asia and The Pacific, RAP Publication 2007 / 20.

Farag, M.R., Alagawany, M., El-Hack, M. E. A., Tiwari, R., Dhama, K. 2015. Identification of Different Animal Species in Meat and Meat Products: Trends and Advances. Jour. of Adv. Anim. Vet. Sci. 3(6): 334 - 346.

Girindra, Aisjah. (2006). Menjamin Kehalalan dengan Label Halal.Persfektif Food Review Indonesia Vol.1 No 9.hal.12-13. Bogor.

Ilhak, O.I., Arslan, A. 2007. Identification of Meat Species by Polymerase Chain Reaction (PCR) Technique.Turk. J. Vet. Anim. Sci: 31(3): 159-163.

Janosi, A. 2006.Species Specific Detection of Meat by Polymerase Chain Reaction Techniques.Corvinus University of Budapest, Budapest, Rumania.

Joshi, M., Deshpande, J.D. 2010. Polymerase Chain Reaction: Methods, Principles and Application. International Journal of Biomedical Research 1 (5) 81 - 97. 
Jonker, K.M., Tilburg, J.J.H.C., Hagele, G.H., Boer, E.D. 2008. Species Identification in Meat Products Using Real - Time PCR. Food Aditives and Contaminants: Part A, 25:5, 527 - 533.

Margawati, E.T., Ridwan, M. 2010 Pengujian Pencemaran Daging Babi Pada Beberapa Produk Bakso Dengan Teknologi PCR: Pencarian Sistem Pengujian Efektif. Jurnal Ilmu - Ilmu Hayati : Berita Biologi, Vol 10 (1): 93 - 98 (2010).

Mursyidi, A. 2012. The Role Of Chemical Analysis in the Halal Authentication of Food and Pharmaceutical Products. J. Food Phar.Sci. 1 (2013) 1 - 4.

Murugaiah, C., Noor, Z.M., Mastakim, M., Bilung, L.M., Selamat, J., Radu, S. 2009. Meat Species Identification and Halal Authentication Analysis Using mitochondrial DNA. Elsevier Journal of Meat Science 83 (2009) 57 - 61.

Pascoal, A., Prado, M., Castro, J., Cepeda, A. 2004. Survey of Authenticity of Meat Species in Food Products Subjected to Different Technological Processes, of PCR - RFLP Analysis. Eur. Food Res. Technol. 218: 306 -312.

Sahilah, A.M., Norhayati, Y., Norrakiah, A. S., Aminah, A. and Wan Aida, W. M. 2011.Halal Authentication of Raw Meats Using PCR Amplification of Mitochondrial DNA.International Food Research Journal 18(4): 1489-1491 (2011)

Salehudin, I. 2010. Halal Literacy: A Concept Exploration and Measurement Validation. Dept. of Management, Faculty of Economics, University of Indonesia.Asean Marketing Journal, June 2010 - Vol. II - No. 1.

Srihanto, Setiaji, E.A., Rumpaka, G., Firwantoni. 2011. Identifikasi Daging Tikus Pada Produk Asal Hewan Dengan Menggunakan Teknik Polimerase Chain Reaction (PCR).Prosiding Seminar Nasional Sains dan Inovasi Teknologi Pertanian.

Unajak, S., Meesawat, P., Anyamaneeratch, K. Anuwareepong, D., Srikulnath, K., Choowongkomon, K. 2011. Identification of Species (Meat and Blood Samples) Using Nested-PCR Analysis of Mitochondrial DNA.
African Journal of Biotechnology Vol. 10(29), pp. 5670-5676, 22 June, 2011.

Wardani, A.K. dan Sari, E. P. K. 2015.Deteksi Molekuler Cemaran Daging Babi Pada Bakso Sapi Di Pasar Tradisional Kota Malang Menggunakan PCR.Jurnal Pangan dan Agroindustri Vol.3 No 4 p. 1294 1301, September 2015.

Widyasari, Y. I., Sudjadi., Rohman, A. 2015. Detection of Rat Meat Adulteration in Meat Ball Formulations Employing Real Time PCR. Asian Journal of Animal Sciences 9 (6): 460 $-465,2015$.

Zidek, R., Bajzik, P., Marsalkova, L., Golian, J. Detection of Counterfeit Beef Using Real - Time PCR. 2011. Dept. of Hygiene and Food Safety, Slovak University of Agriculture in Nitra. 